\title{
The Effect of Learning Models and Multiple Intelligences on Mathematics Achievement
}

\section{La Ndia}

Dr., Department of Mathematics Education, Halu Oleo University, Kendari, Indonesia, alndifiat@gmail.com

\section{Etin Solihatin}

Dr., Department of Educational Technology, Jakarta State University, Indonesia, etinsolihatin@yahoo.com

\section{Zulfiati Syahrial}

Prof., Department of Educational Technology, Jakarta State University, Indonesia, zulfiati@unj.ac.id

The purpose of this study was to determine the effect of learning models and multiple intelligences on mathematics achievement. It was conducted at SMPN 5 Kendari, Southeast Sulawesi, Indonesia. The research method used a quasiexperimental design. Data on mathematics achievement and multiple intelligences were collected using multiple-choice tests. The collected data were analyzed using a two-way ANOVA. The findings of this study showed that student mathematics achievement taught with PBL model was higher than those taught with direct learning model; mathematics achievement of students with mathematical logic intelligence was higher than those with spatial intelligence; there was an effect of interaction between learning models and multiple intelligences on student mathematics achievement; mathematics achievement of students with spatial intelligence taught with PBL model was higher than students taught with direct learning model; mathematics achievement of students with mathematical logic intelligence taught by PBL model was higher than those taught with direct learning model; there was no significant difference in mathematics achievement between students with spatial intelligence and mathematical logic intelligence taught by PBL model; mathematics achievement of students with mathematical logic intelligence was higher than those with spatial intelligence taught by direct learning model.

Keywords: PBL model, direct model, spatial intelligence, mathematical logic intelligence, students' achievement 


\section{INTRODUCTION}

Mathematics is the queen of science (Perutz, and Jenkin, 1989) because the development of other sciences, especially in the field of science, is based on the development of mathematical concepts (Kirkland, 2010). Therefore, a student must be able to master and/or be smart in mathematics so that it is easier to develop his ideas into other fields, especially in the field of science (Abtar, and Mohammed, 2019). The reality now is from year to year, mathematics achievements in schools are still low (Ministry of Education and Culture, 2011). One of the reasons is abstract mathematical objects (Korn, and Korn, 2010; Josseph, 2010) where most students are not able to analyze them. Therefore, a teacher must have the ability to translate abstract mathematical objects into concrete ones (Orton, and Frobisher 2004; Wu, 2011; Bremigan et al., 2011). This can be done by the use of real things (Demelo, 2007), namely tangible or concrete things that can be observed, understood by students to facilitate the learning process so that it reaches its goals.

Mathematics is one of the most objectives, logical and practical disciplines (Lai et al., 2015). It is a language symbolic that allows humans to think about quantity problems and can connect between quantities and others (Yarmohammadian, 2014). Therefore, in learning mathematics, the teacher must be able to see the whole problem carefully to find a right learning pattern based on students' characteristics and their level of intelligence. Mastery of mathematics for students is very necessary because mathematics is the basis for all world technologies (Mbugua, andMuthoni, 2014).

Learning mathematics is a series of processes to discover mathematical concepts themselves, procedures for solving contextual problems based on ideas and stages developed by students (Barnes, 2004), by using their own language to solve mathematical problems, which is called as informal mathematics.

Completion of informal mathematics is a bridge to the completion of formal mathematics (Widjaja, and Heck, 2003). Formation of mathematics is formally based on the actual mathematical context through the use of mathematical language, general symbols, and algorithm of problem-solving based on standard rules.

Based on the description above, the task of a teacher is not easy because the teacher must be able to design a learning process that can facilitate students to learn and be able to apply those effective learning models. The implementation of an effective learning model can increase student grades (Reigeluth, and Carr-Chellman, 2009). In addition to considering learning models that are relevant to the subject matter, the teacher must also consider the characteristics and level of intelligence possessed by students when designing material.

Learning model used at SMPN 5 Kendari, Southeast Sulawesi, Indonesia, is direct learning model that is teacher-centered where students are passive recipients of information without trying other learning models that can activate students and support understanding concepts, facts, principles, and generalization, Consequently, increasing mathematics achievement from year to year is not significant. 
In order to improve students' creativity, the learning process done by the teacher must be able to develop students 'creative thinking, as well as to improve students' abilities to construct new knowledge and ideas in order to improve good mastery of mathematics subject matter.

One learning model that can activate students and support the understanding of concepts, facts, principles, and generalizations is Problem Based Learning (PBL). PBL model is an innovative and student-centered learning model which simultaneously challenges students for critical thinking (Lowenstein, and Bradshaw, 2004). PBL model using Realistic Mathematics Approach (PMR) aims at helping students to improve their creativity in developing new ideas by utilizing real or concrete situations that can be observed and or understood by students, as well as by utilizing environment to develop thinking skills and problem-solving skills, to increase self-confidence possessed to think critically and to become independent students.

According to Ibrahim et al., the PBL model can improve students' knowledge and skills (Ibrahim et al., 2018).

Based on the description above, it is necessary to conduct a study on the effect of PBL model and direct learning model in teaching mathematics.

\section{LITERATURE REVIEW}

Constructivism learning theory is a foundation of thinking in a contextual approach. The philosophy of this approach is that knowledge is built by students through exploration activities and discussions with their friends. Knowledge is not a set of facts, concepts, or rules that are ready to be taken and used by students, but students must construct their own knowledge. Changes in perspective in the learning process are the basis for designing innovative learning models.

Along with the development of science and technological progress, more innovative learning models are found that are rooted in a constructivism learning theory. Therefore, a teacher is required to be able to choose an effective learning model and can spur students' enthusiasm, motivation, and independence so that they are actively involved in the learning process. The implementation of effective learning models allows students to obtain higher grades so that a teacher must consider relevant learning models when designing learning (Reigeluth, and Carr-Chellman, 2009).

A learning model is a specific method to facilitate learning that is designed to promote learning outcomes related to the standards needed in academic disciplines through the use of a series of specially designed activities. Therefore, special skills and expertise from teachers are needed in designing learning models to enhance students' creativity for the sake of developing their skills and critical thinking skills so that they are able to solve the problems faced in relation to the learning process which in the end can increase their achievement.

Eggen, and Kauchak said that the PBL model is an active learning model that allows students to learn and hone problem solving skills, to develop competencies with standards academic content, and to realize the relevance of applying it to learn 
according to content for practical purposes (Eggen, and Kauchak, 2012). Another definition of PBL is a set of teaching model that uses problems as a focus for developing problem-solving skills, material and self-regulation (Kilbane, and Milman, 2013).

From the definition of PBL model above, it could be stated that PBL model is one of the student-centered learning models where students act as active participants in the learning process while also providing challenges to students to improve their critical thinking skills so that they are able to construct knowledge in their own minds. It means that the information or knowledge that they produce is their own.

The direct learning model is based on BF Skinner's behaviorism theory (1953), which emphasizes the understanding that human behavior basically has a relationship between stimulus and response. In this case, learning outcomes focus on measurable and observable behavior (Ormrod, Anderman, and Anderman, 2016).

The direct learning model is one of the learning models which in its implementation, teachers act as a source of information (Arend, 2012). This model involves demonstrations and teachers' explanations accompanied by student exercises and feedback to help them acquire real knowledge and skills needed for further learning.

Mathematical logic intelligence and spatial intelligence are part of eight types of multiple intelligences developed by Howard Gardner, both of which are closely related to the field of mathematics. According to Gardner, mathematical logic intelligence includes the ability to analyze problems logically, to solve mathematical problems, especially problems in mathematical operations, and to investigate a problem based on scientific principles. (Gardner, 2011). According to Baum's View, Viens B, and Slatin $\mathrm{B}$, there are two keywords of mathematical logic intelligence namely; (1) allowing individuals to use and to understand abstract relationships, and (2) skills in using numbers and logical thinking.

Students with high mathematical logic intelligence tend to have the ability to analyze and to investigate problems logically, to understand abstract relationships, the ability to process numbers and measure and have the ability to use logical thinking and be able to argue well. Students with such abilities easily learn mathematics, which in turn will improve their learning achievement.

While spatial intelligence is related to the dimensions of space problems. According to Taylor, spatial intelligence is the ability to think in three dimensions in terms of spatial reasoning, mental image, image manipulation, graphic and artistic skills, and active imagination (Taylor 2013). While according to Mckee, spatial intelligence is the ability to visualize concepts and relationships between concepts (Mckee, 2004). Whereas according to Ross, spatial intelligence can also be expressed as the ability to have the sensitivity to adapt to visual forms that look sharp, balance, color, lines, shapes, and space (Ross, 2005).

Students who have high spatial intelligence could easily read maps, graphics, images, and think in pictures. They can visualize images clearly and can solve jigsaw puzzles easily. Images can provide contextual instructions for words and help students in 
learning to read and to spell and also to recognize relationships between objects. The use of those images is very effective because every time students hear a word, they see a picture of the word and in the picture, there is a correct spelling. Remembering images allows them to translate images into words to a written page.

If students have high intelligence, they are taught with a student-centered learning model, they easily develop their potential, improve their ability to analyze problems so that the problem can be properly addressed. Therefore, the use of PBL model by using PMR greatly helps students to develop their learning independence through the realworld and environment that are used as a starting point in learning and developing mathematical concepts, sharpening and developing problem-solving skills. Students are given the widest opportunity to develop mathematical knowledge that they have through teacher guidance in an organized and systematic way that simultaneously trains critical thinking skills.

\section{Statement of Problems}

Students' low learning achievement is felt by almost all parts of the world, including Indonesia (Ministry of Education and Culture, 2011). Various causal factors include (1) abstract mathematical objects (Korn, and Korn, 2000), causing the students are not able to analyze them, (2) student's low creativity in learning, (3) teachers' readiness to teach, one of which is the use of inappropriate learning strategies (Salman et al., 2012) in (Adenji et al., 2018). Most teachers still use the old pattern by using a direct learning model. Most teachers explain mathematical material and practice solving problems based on standard rules, consequently students are only fixated on the rules and unable to develop their learning creativity based on their potential. When active, creative, and explorative students with certain potential or multiple intelligences are taught by using direct learning model, they will turn into students who are apathetic, bored, lazy, and lack of creativity in learning. Such conditions tend to affect student achievement because of the indirect learning model where the teacher dominates the process of learning activities. The teacher is the only source of information in learning. They tend to take control of the learning process actively, while students pay attention, listen, accept and follow what the teacher says. Such condition could probably cause the students having a lack of direct experience in terms of finding facts, concepts, procedures, and solving problems systematically and finding relationships between facts and mathematical concepts.

One learning model that can activate student creativity is PBL model, which is an active learning model that allows students to learn and sharpen problem-solving skills, to develop competencies with academic content standards, and to realize the relevance of implementing learning in accordance with content for practical purposes (Kilbane, and Milman, 2013). Another definition of PBL is problem-based learning characterized by students who work with one another, can be in pairs or small groups. Through cooperation or groups, they provide mutual motivation with one another, for continuous involvement in complex tasks and increasing opportunities for joint inquiry and discussion, for the development of social skills (Arend, 2012). From the definition above, it can be concluded that in PBL, students are given the freedom to create and 
actively develop their potential to practice problem-solving skills, either by themselves or by groups, from simple problems to complex ones.

Research on the effect of PBL on student mathematics achievement have been done, such as Pradnyana et al., (2013), Rohmah (2013), Firdaus et al., (2017), Hussain et al., (2019) in different studies reported that there were significant differences in mathematical critical thinking skills between students taught with PBL and conventional learning model, the use of PBL in mathematics can significantly improve mathematics achievement and critical thinking skills, and it is more effective in improving students' mathematical literacy.

Realistic mathematics learning (PMR) aims at helping students to develop thinking skills and problem solving skills, to enhance self-confidence possessed to think critically and to become independent students, to make mathematical objects more interesting because they are no longer abstract, to emphasize learning mathematics by learning by doing, to utilize real or concrete things that can be observed by students, as well as to make use of environment.

From the description above, it can be concluded that PBL using the PMR approach can improve students' creativity, systematic problem-solving abilities, critical thinking skills, and mathematics achievement, by making mathematical objects more interesting by utilizing observable real world and utilizing the environment.

\section{Research Objectives}

The main objective of the study was to determine the effect of learning models and multiple intelligences on mathematics achievement. Specifically, this study aims at finding out:

1. Is mathematics achievement of students taught with PBL higher than those taught by direct learning model?

2. Are there significant differences in mathematics achievement between students with spatial intelligence and mathematical logic intelligence?

3. Is there an effect of interaction between learning models and multiple intelligences on mathematics achievement?

4. Is the mathematics achievement of students with mathematical logic intelligence taught with PBL higher than students taught with the direct learning model?

5. Are there significant differences in mathematics achievement between students with mathematical logic intelligence and students with spatial intelligence taught using direct learning model?

6. Is mathematics achievement of students with spatial intelligence taught with PBL higher than students taught with the direct learning model?

Are there significant differences in mathematics achievement between students with spatial intelligence and those with mathematical logic intelligence taught using the PBL? 


\section{METHOD}

This study used quasi-experiments design by involving two variables. Independent variable consisted of: (1) treatment variables, namely learning model consisting of Problem Based Learning (PBL) model using Realistic Mathematics Approach (PMR) $\left(A_{1}\right)$ and direct learning model $\left(A_{2}\right)$, and (2) moderator variables, namely multiple intelligences consisting of mathematical logic intelligence $\left(B_{1}\right)$, and spatial intelligence $\left(B_{2}\right)$, while dependent variable was mathematics achievement.

The research design used a $2 \times 2$ factorial design. The design model was presented in table 1. (Montgomeri, 2017).

Table 1

Factorial Design 2X2

\begin{tabular}{lll}
\hline \multirow{2}{*}{ Moderator variable } & Treatment variable \\
\cline { 2 - 3 } & PBL through PMR $\left(\mathrm{A}_{1}\right)$ & Direct learning model $\left(\mathrm{A}_{2}\right)$ \\
\hline Logic mathematic intelligence $\left(\mathrm{B}_{1}\right)$ & $\mathrm{A}_{1} \mathrm{~B}_{1}$ & $\mathrm{~A}_{2} \mathrm{~B}_{1}$ \\
Spatial intelligence $\left(\mathrm{B}_{2}\right)$ & $\mathrm{A}_{1} \mathrm{~B}_{2}$ & $\mathrm{~A}_{2} \mathrm{~B}_{2}$ \\
\hline
\end{tabular}

$\mathrm{A}_{1} \mathrm{~B}_{1}$ Group of students taught with PBL with mathematical logic intelligence

$A_{1} B_{2}$ Group of students taught with PBL with spatial intelligence

$\mathrm{A}_{2} \mathrm{~B}_{1}$ Group of students taught with direct learning model with mathematical logic intelligence

$\mathrm{A}_{2} \mathrm{~B}_{2}$ Group of students taught with direct learning model with spatial intelligence

The population in this study was all eighth-grade students of SMPN 5 Kendari, Southeast Sulawesi, Indonesia, who were enrolled in the odd semester of the 2018/2019 academic year, consisting of 10 parallel classes with 388 students. The sample was chosen by using purposive sampling techniques, with the aim at obtaining two classes as samples whose scores were relatively the same based on the average value and variance. With those considerations, class VIII A and class VIII B were chosen as samples, consisting of 62 students (class VIIIA 31 students, and class VIIIB 31 students). The determination of the experimental class and control class was carried out by a simple random method, using a lottery method. The result of randomization was that class VIII A as the experimental class was taught with the PBL model using PMR, and class VIII $\mathrm{B}$ as the control class was taught by a direct learning model. The number of samples in each group was presented in Table 2 below:

Table 2

Distribution of Samples in Each Cell

\begin{tabular}{lllll}
\hline $\begin{array}{l}\text { Moderator } \\
\text { Variable }(\mathrm{B})\end{array}$ & $\begin{array}{l}\text { Treatment } \\
\text { Variable }(\mathrm{A})\end{array}$ & $\begin{array}{l}\text { PBL Through } \\
\text { PMR }\left(\mathrm{A}_{1}\right)\end{array}$ & $\begin{array}{l}\text { Direct Learning } \\
\text { Model }\left(\mathrm{A}_{2}\right)\end{array}$ & Total \\
\hline $\begin{array}{l}\text { Logic } \\
\text { Mathematics }\end{array}$ & 14 & 15 & 29 \\
$\begin{array}{l}\text { Intelligence }\left(\mathrm{B}_{1}\right) \\
\text { Spatial }\end{array}$ & 17 & 16 & 33 \\
Intelligence $\left(\mathrm{B}_{2}\right)$ & & 31 & 31 & 62 \\
\hline Total & & & & \\
\hline
\end{tabular}


Grouping of samples of the moderator variable was based on the score of spatial intelligence and mathematical logic intelligence test. If the score of spatial intelligence test was higher than the mathematical logic intelligence score, students were included in the group of mathematical logic intelligence $\left(B_{1}\right)$, otherwise if the score of mathematical logic intelligence test was higher than the spatial intelligence score, the students were included in the group of spatial intelligence $\left(\mathrm{B}_{2}\right)$.

Instruments used to collect data were a set of tests arranged in the form of multiplechoice tests. Tests of mathematics achievement and mathematical logic intelligence were compiled by researchers, while spatial intelligence tests used standardized tests. Before being used to collect data, all tests were validated, namely content, construct, and empirical validity. Content and construct validity were carried out by experts in accordance with their respective fields, while empirical validity was done through a pilot study. It was carried out at class X SMPN 5 Kendari with the consideration that they had studied the two-variable linear equation system. The result of validity for mathematics test was that there were 31 valid items of 35 items tested with a reliability level 0.88 , all 45 items for spatial intelligence test were declared valid with a reliability level 0.89 , and there were 34 valid items of 36 items for mathematical logic intelligence test with a reliability level 0.91 . With those levels of reliability, the instrument can be used to collect data.

Data analysis was done by; (1) descriptive statistical analysis used to calculate the average value, variance, and standard deviation, (2) prerequisite test of inferential statistical analysis including normality test and variance homogeneity test, and (3) inferential statistical analysis using two-way analysis of variance (ANOVA). If there was an interaction between learning models and multiple intelligences, then further test was analyzed using a t-test, (Phakiti, 2014) to find out which treatment groups were higher or which groups differed significantly.

\section{FINDINGS}

The results of the descriptive analysis are presented in table 3 below 
Table 3

$\underline{\text { Results of Descriptive Analysis }}$

\begin{tabular}{|c|c|c|c|c|}
\hline \multirow{3}{*}{$\begin{array}{l}\text { Multiple } \\
\text { Intelligence } \\
\text { (B) }\end{array}$} & \multirow{3}{*}{ Statistical data } & \multicolumn{2}{|c|}{ Learning Model (A) } & \multirow{3}{*}{$\begin{array}{l}\text { Students' } \\
\text { achievement }\end{array}$} \\
\hline & & $\mathrm{A}_{1}$ & $\mathrm{~A}_{2}$ & \\
\hline & & $\begin{array}{l}\text { Students' } \\
\text { achievement }\end{array}$ & $\begin{array}{l}\text { Students' } \\
\text { achievement }\end{array}$ & \\
\hline \multirow{6}{*}{$\mathrm{B}_{1}$} & $\mathrm{~N}$ & 14 & 15 & 29 \\
\hline & Average & 79.49 & 70.32 & 74.75 \\
\hline & Variance & 21.38 & 54.38 & 69.75 \\
\hline & Standard of deviation & 4.62 & 7.37 & 8.35 \\
\hline & Maximum & 90 & 84 & 90 \\
\hline & Minimum & 74 & 58 & 58 \\
\hline \multirow{6}{*}{$\mathrm{B}_{2}$} & $\mathrm{n}$ & 17 & 16 & 33 \\
\hline & Average & 77.32 & 60.28 & 69.21 \\
\hline & Variance & 32.38 & 32.60 & 128.28 \\
\hline & Standard of deviation & 5.69 & 5.71 & 11.33 \\
\hline & Maximum & 90 & 68 & 90 \\
\hline & Minimum & 71 & 52 & 52 \\
\hline \multicolumn{2}{|r|}{ 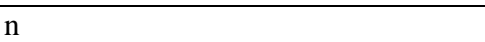 } & 31 & 31 & \\
\hline \multicolumn{2}{|l|}{ Average } & 78.46 & 65.14 & \\
\hline \multicolumn{2}{|c|}{ Variance } & 25.63 & 44.37 & \\
\hline \multicolumn{2}{|c|}{ Standard of deviation } & 5.06 & 6.67 & \\
\hline \multicolumn{2}{|c|}{ Maximum } & 90 & 84 & \\
\hline \multicolumn{2}{|l|}{ Minimum } & 71 & 52 & \\
\hline
\end{tabular}

Research Question 1: Are mathematics achievement of students taught with the PBL model higher than students taught with the direct learning model presented in Table 2. Hypothesis 1: Mathematics achievement of students taught with the PBL model was higher than students taught with direct learning model.

$\mathrm{H} 0: \mu \mathrm{A}_{1}=\mu \mathrm{A}_{2}$

$\mathrm{H} 1: \mu \mathrm{A}_{1}>\mu \mathrm{A}_{2}$

The results of descriptive analysis (table 3) showed that the average mathematics achievement of students taught with the PBL model (78.46) was higher than the average mathematics achievement of students taught with direct learning model (65.14).

The results of inferential statistical analysis are presented in table 4 below.

Table 4

Results of Variance Analysis

\begin{tabular}{llllll}
\hline Source of Variance & $\begin{array}{l}\text { Sum of } \\
\text { Squares (SS) }\end{array}$ & df & $\begin{array}{l}\text { Mean Square } \\
\text { (MS) }\end{array}$ & F-count & F-table \\
\hline Main Effect (A) & 2749.8248 & 1 & 2749.8248 & 42.1077 & 4.0069 \\
Main Effect (B) & 473.9839 & 1 & 473.9839 & 7.2581 & 4.0069 \\
Interaction (A X B) & 333.7003 & 1 & 333.7003 & 5.1099 & 4.0069 \\
Error Term (Within Groups) & 3787.6629 & 58 & 65.30453 & & \\
Total & $7345, .1719$ & 61 & & & \\
\hline
\end{tabular}


The results of the two-way ANOVA test (Table 4) showed that the source of variance between $\mathrm{A}$ was obtained $\mathrm{F}$-count $=42.1077$ greater than $\mathrm{F}_{\text {-table }}=40069$, with $\alpha=0.05$. This means that there were significant differences in mathematics achievement between students taught with the PBL model $\left(\mathrm{A}_{1}\right)$ and those taught with direct learning model $\left(\mathrm{A}_{2}\right)$. T-test results (table 5) showed that $\mathrm{t}$-count $\left(\mathrm{A}_{1}\right.$ vs $\left.\mathrm{A}_{2}\right)=3.4520$ was higher than $\mathrm{t}$ -

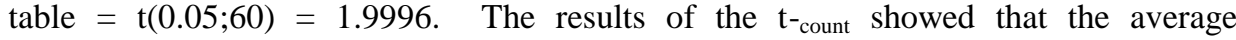
mathematics achievement of students taught with the PBL model was significantly higher than the mathematics achievement of students taught with a direct learning model. These results indicated that hypothesis 1 was accepted.

Table 5

Summary of Further Tests A1 vs A2

\begin{tabular}{llll}
\hline Compared Groups & df & $\mathrm{t}-$ count $_{\text {t }}$ & $\mathrm{t}$-table \\
\hline $\mathrm{A}_{1}$ with $\mathrm{A}_{2}$ & 60 & 3.4520 & 1.9995 \\
\hline
\end{tabular}

Research question 2: Are there significant differences in mathematics achievement between students with spatial intelligence and mathematical logic intelligence?

Hypothesis 2: There were significant differences in mathematics achievement between students with spatial intelligence and those with mathematical logic intelligence.

$\mathrm{H}_{0}: \mu_{\mathrm{B} 1}=\mu_{\mathrm{B} 2}$

$\mathrm{H}_{1}: \mu_{\mathrm{B} 1}>\mu_{\mathrm{B} 2}$

The results of descriptive analysis (table 3 ) showed that the average mathematics achievement of students with mathematical logic intelligence (74.75) was higher than the average mathematics achievement of students with spatial intelligence (69.21).

The results of the two-way ANOVA test (Table 4) showed that the source of variance between $\mathrm{B}$ was $\mathrm{F}$-count $=7.2581$ greater than the value of $\mathrm{F}_{\text {-table }}=4.0069$, with $\alpha=0.05$. This means that there were significant differences in mathematics achievement between students with mathematical logic intelligence $\left(\mathrm{B}_{1}\right)$ and students with spatial intelligence $\left(B_{2}\right)$. The $t$-test results (Table 6 ) showed that $t$-count $\left(B_{1}\right.$ vs $\left.B_{2}\right)=2.1063$ was higher than $t$ table $=1.6702$; The t-test results showed that the average of mathematics achievement of students with mathematical logic intelligence was significantly higher than the mathematics achievement of students with spatial intelligence. These results indicated that hypothesis two was accepted.

Table 6

Summary of Further Tests B1 vs B2

\begin{tabular}{llll}
\hline Compared Groups & $\mathrm{df}$ & $\mathrm{t}$-count & $\mathrm{t}$-table \\
\hline $\mathrm{B}_{1}$ with $\mathrm{B}_{2}$ & 60 & 2.1063 & 1.6702 \\
\hline
\end{tabular}

Research question 3: Is there the effect of interaction between models of learning and multiple intelligences on mathematics achievement?

Hypothesis 3: There was an effect of interaction between learning models and multiple intelligences on mathematics achievement. 
$\mathrm{H}_{0}: \mu_{\mathrm{AB}}=0$

$\mathrm{H}_{1}: \mu_{\mathrm{AB}} \neq 0$

The results of the two-way ANOVA test (table 4) showed that the source of AXB interaction variance was F-count $=5.1099$, and F-table $=4.0069$, with $\alpha=0.05$. This means that there was a significant effect of interaction between multiple intelligences and learning models. These results indicated that hypothesis 3 was accepted.

Research question 4: Are mathematics achievement of students with mathematical logic intelligence taught with the PBL model higher than students with mathematical logic intelligence taught with direct learning model?

Hypothesis 4: Mathematical achievement of students with mathematical logic intelligence taught with the PBL model was higher than students taught with the direct learning model.

$$
\begin{aligned}
& \mathrm{H} 0: \mu_{\mathrm{A} 1 \mathrm{~B} 1}=\mu_{\mathrm{A} 2 \mathrm{~B} 1} \\
& \mathrm{H} 1: \mu_{\mathrm{A} 1 \mathrm{~B} 1}>\mu_{\mathrm{A} 2 \mathrm{~B} 1}
\end{aligned}
$$

The results of descriptive analysis (table 3) showed that the average of students with mathematical logic intelligence taught with the PBL model $\left(\mathrm{A}_{1} \mathrm{~B}_{1}\right) 79.49$ was higher than the average of students with mathematical logic intelligence taught with direct learning model $\left(\mathrm{A}_{2} \mathrm{~B}_{1}\right) 70.32$. The results of $\mathrm{t}$-test (Table 7$)$ showed that $\mathrm{t}$-count $\left(\mathrm{A}_{1} \mathrm{~B}_{1} \mathrm{vs}\right.$ $\left.\mathrm{A}_{2} \mathrm{~B}_{1}\right)=4.4346$ was greater than the value of $\mathrm{t}$-table $=2.0484$ with $\alpha=0.05$; The $\mathrm{t}$-test results showed that the average of students with mathematical logic intelligence taught with PBL model was significantly higher than that of students with mathematical logic intelligence taught by direct learning model. These results indicated that hypotheses 4 was accepted

Table 7

Summary of Further Tests A1B1 vs A1B2

\begin{tabular}{llll}
\hline Compared Groups & Df & $\mathrm{t}$-count & $\mathrm{t}_{\text {-table }}$ \\
\hline $\mathrm{A}_{1} \mathrm{~B}_{1}$ with $\mathrm{A}_{1} \mathrm{~B}_{2}$ & 27 & 4.4346 & 2.0484 \\
\hline
\end{tabular}

Research question 5: Are there significant differences in mathematics achievement between students with mathematical logic intelligence and students with spatial intelligence taught with direct learning model?

Hypothesis 5: There was a significant difference in mathematics achievement between students with mathematical logic intelligence and students with spatial intelligence taught with direct learning model.

$\mathrm{H}_{0}: \mu_{\mathrm{A} 2 \mathrm{~B} 1}=\mu_{\mathrm{A} 2 \mathrm{~B} 2}$

$\mathrm{H}_{1}: \mu_{\mathrm{A} 2 \mathrm{~B} 1}>\mu_{\mathrm{A} 2 \mathrm{~B} 2}$

The results of descriptive analysis (table 3 ) showed that the average of students with mathematical logic intelligence taught with direct learning model $\left(\mathrm{A}_{2} \mathrm{~B}_{1}\right) 70.33$ was higher than the average of students with spatial intelligence taught with direct learning 
model $\left(\mathrm{A}_{2} \mathrm{~B}_{2}\right)$ 60.28. The results of $\mathrm{t}$-test $($ Table 8$)$ showed that $\mathrm{t}$-count $\left(\mathrm{A}_{2} \mathrm{~B}_{1}\right.$ vs $\left.\mathrm{A}_{2} \mathrm{~B}_{2}\right)=$ 2.9030 was greater than $\mathrm{t}$-table $=1.6973$, with $\alpha=0.05$; The $\mathrm{t}$-test results showed that the average of students with mathematical logic intelligence taught with direct learning model was significantly higher than that of students with spatial intelligence taught with direct learning model. These results indicated that hypotheses 5 were accepted.

Table 8

Summary of Further Tests A2B1 vs A2B2

\begin{tabular}{llll}
\hline Compared Groups & $\mathrm{df}$ & $\mathrm{t}$ - $_{\text {count }}$ & $\mathrm{t}$-table \\
\hline $\mathrm{A}_{2} \mathrm{~B}_{1}$ with $\mathrm{A}_{2} \mathrm{~B}_{2}$ & 29 & 2.9030 & 1.6973 \\
\hline
\end{tabular}

Research question 6: Is the mathematics achievement of the student with spatial intelligence taught with the PBL model higher than the student taught with direct learning model?

Hypothesis 6: Mathematics achievement of students with spatial intelligence taught with PBL model higher than student taught with direct learning model.

$\mathrm{H}_{0}: \mu_{\mathrm{A} 1 \mathrm{~B} 2}=\mu_{\mathrm{A} 2 \mathrm{~B} 2}$

$\mathrm{H}_{1}: \mu_{\mathrm{A} 1 \mathrm{~B} 2}>\mu_{\mathrm{A} 2 \mathrm{~B} 2}$

The results of descriptive analysis (Table 3) showed that the average of students with spatial intelligence taught with the PBL model (A1B2) 77.61 was higher than the average of students with spatial intelligence taught with direct learning model (A2B2) 60.28. The results of the t-test (Table 9) showed that $t$-count $\left(A_{1} B_{2}\right.$ vs $\left.A_{2} B_{2}\right)=5.0267$ was greater than $\mathrm{t}$-table $=2.0369$, with $\alpha=0.05$. The t-test results showed that the average of students with spatial intelligence taught with the PBL model was significantly higher than that of students with spatial intelligence taught with direct learning model. These results indicated that hypothesis 6 was accepted.

Table 9

Summary of Further Tests A1B2 vs A2B2

\begin{tabular}{llll}
\hline Compared Groups & $\mathrm{df}$ & $\mathrm{t}$-count $_{\text {t }}$ & $\mathrm{t}_{\text {table }}$ \\
\hline $\mathrm{A}_{1} \mathrm{~B}_{2}$ with $\mathrm{A}_{2} \mathrm{~B}_{2}$ & 31 & 5.0267 & 2.0369 \\
\hline
\end{tabular}

Research question 7: Are there significant differences in mathematics achievement between students with mathematical logic intelligence and students with spatial intelligence taught with the PBL model?

Hypothesis 7: There were significant differences in mathematics achievement between students with mathematical logic intelligence and students with spatial intelligence taught with the PBL model.

$\mathrm{H}_{0}: \mu_{\mathrm{A} 1 \mathrm{~B} 1}=\mu_{\mathrm{A} 1 \mathrm{~B} 2}$

$\mathrm{H}_{1}: \mu_{\mathrm{A} 1 \mathrm{~B} 1} \neq \mu_{\mathrm{A} 1 \mathrm{~B} 2}$

The results of descriptive analysis (table 3 ) showed that the average of students with mathematical logic intelligence taught with the PBL model $\left(A_{1} B_{1}\right) 79.49$ was higher 
than that of students with spatial intelligence taught with PBL model $\left(\mathrm{A}_{1} \mathrm{~B}_{2}\right)$ 77. 61. The results of $t$-test (Table 10) showed that $t$-count $\left(\mathrm{A}_{1} \mathrm{~B}_{1}\right.$ vs $\left.\mathrm{A}_{1} \mathrm{~B}_{2}\right)=-0.9244$ was between $\mathrm{t}-$ table $=-1.6973$ dan $t_{\text {table }}=1.6973$, with $\alpha=0.05$. The t-test results showed that the average of students with mathematical logic intelligence taught with the PBL model did not differ significantly from that of with spatial intelligence taught with the PBL model. These results indicated that hypothesis 7 was rejected.

Table 10

Summary of Further Tests A1B1 vs A1B2

\begin{tabular}{llll}
\hline Compared Groups & Df & $t$ - $_{\text {count }}$ & $t$ table \\
\hline $\mathrm{A}_{1} \mathrm{~B}_{1}$ with $\mathrm{A}_{1} \mathrm{~B}_{2}$ & 29 & -0.9244 & 1.6973 \\
\hline
\end{tabular}

\section{DISCUSSION}

This study revealed the effect of learning models and multiple intelligences on the mathematics achievement of students of SMPN 5 Kendari, Southeast Sulawesi, Indonesia. The findings of this study were that there was a significant effect of interaction between learning models and multiple intelligences on mathematics achievement. This finding was in line with Roediyanto's study (2014) who concluded that there was effect of interaction between models of learning and multiple intelligences on physical education achievement on elements of creativity development. Ratnasari et al. (2018) found that there was an interaction between multiple intelligences and learning models on improving scientific attitudes and student achievement in the field of science. Arismayani, Yusuf, and Latuconcina (2015) concluded that there was effect of interaction between learning strategies and mathematical logic intelligence on student mathematics achievement.

One of the objectives of developing learning models is to make it easier for students to learn optimally, both independently and in groups that can eventually develop their abilities in constructing new knowledge based on ideas or knowledge they have. The PBL model using the PMR approach is one of the innovations in learning that is designed to optimize students' thinking skills, to solve problems through systematic independent work processes, so that students can empower, sharpen, test, and develop their ability to think continuously, through real-world and environment used as a starting point in learning and developing mathematical concepts. Students are given the widest opportunity to build mathematical knowledge that they have through teacher guidance (Sumiratta, Makanong, Thipkong, 2017).

Therefore, the PBL model is designed with the aim at developing independent learning skills (Kilbane, and Miman, 2013), developing the knowledge that students have in an organized and systematic manner that simultaneously trains critical thinking skills (Eggen, and Kauchak, 2012).

The findings of a study conducted by Hussain et al. (2019) revealed that the introduction of the PBL model in training courses on drug administration can improve academic performance, critical thinking skills, and time management abilities. 
Active, creative, and explorative students with certain multiple intelligences taught by using direct learning model will turn out to be students who are apathetic, bored, lazy, and lack of creativity in learning. Such conditions tend to affect their achievement because of the indirect learning model where the teacher tends to dominate the process of learning activities. The teacher is the only source of information in learning who takes control of the learning process actively, while students pay attention, listen, accept and follow what is conveyed by teachers. Students tend to have a lack of direct experience in terms of finding facts, concepts, and mathematical procedures and finding relationships between facts and mathematical concepts.

The results of research conducted by Ramirez, and Jones, (2012) concluded that the direct learning model made students feel dependent on the teacher in acquiring their knowledge. In this case, students are unable to connect the mathematical concepts that they have with the new concepts that they are learning. From the description above, it can be concluded that the PBL model using the PMR approach can improve students' mathematics achievement.

The research findings showed that the average of mathematics achievement of students with mathematical logic intelligence was higher and significant than that of with spatial intelligence. The results of research conducted by Pehlivan, and Durgut, (2017) showed that there was a positive correlation between mathematical logic intelligence and students' achievement in Financial Accounting class which means that the higher the mathematical logic intelligence score, the higher the student achievement.

Students with mathematical logic intelligence generally have certain characteristics and skills in terms of processing numbers and/or have skills in using logic or common sense, have the ability to do calculations, make measurements, analyze problems, build hypotheses, and solve problems by considering prepositions in drawing conclusions.

Those characteristics are used to build models and theories in an operating system. Therefore, the mathematical logic intelligence possessed by students is not only limited to the field of mathematics but also includes scientific abilities in other fields. This is because through mathematical logic intelligence, students are able to solve problems by concocting hypothetical abilities and making conclusions. Students with such abilities indicate that they are able to think systemically.

Students with the ability to think systems in solving problems try to solve problems by examining parts of the problem, the interrelationship between problems so that they are able to solve a larger problem.

Students with spatial intelligence generally have higher achievement if the material is related to images, especially geometry material, as explained by the National Council of Teachers of Mathematics (2004) in (Zhang, 2017) that geometry and spatial intelligence are the most basic component of mathematics learning.

\section{CONCLUSION}

Based on the findings and discussion, it can be concluded as follows: 
(a) by using descriptive statistical analysis results.

Table 11

Results of Analysis of Descriptive

\begin{tabular}{lllllllll}
\hline Statistics & $\mathrm{A}_{1}$ & $\mathrm{~A}_{2}$ & $\mathrm{~B}_{1}$ & $\mathrm{~B}_{2}$ & $\mathrm{~A}_{1} \mathrm{~B}_{1}$ & $\mathrm{~A}_{1} \mathrm{~B}_{2}$ & $\mathrm{~A}_{2} \mathrm{~B}_{1}$ & $\mathrm{~A}_{2} \mathrm{~B}_{2}$ \\
\hline Average & 78.46 & 65.14 & 74.75 & 69.21 & 79.49 & 77.32 & 70.32 & 60.28 \\
Variance & 25.63 & 44.37 & 69.75 & 128.28 & 21.38 & 32.38 & 54.38 & 32.60 \\
$\mathrm{n}$ & 31 & 31 & 29 & 33 & 14 & 17 & 15 & 16 \\
\hline
\end{tabular}

(b) mathematics achievement of students taught with PBL models was higher and significant than students taught with direct learning model; (c) mathematics achievement of students with mathematical logic intelligence was higher and significant than students with spatial intelligence; (d) There was an effect of the interaction between learning models and multiple intelligences on mathematics achievement; (e) mathematics achievement of students with mathematical logic intelligence taught with PBL model was higher than students with mathematical logic intelligence taught with direct learning model; (f) mathematics achievement of students with mathematical logic intelligence was higher than students with spatial intelligence taught with direct learning model; $(\mathrm{g})$ mathematics achievement of students with spatial intelligence taught with PBL model was higher than students taught with direct learning model; (h) there was no significant difference in mathematics achievement between students with spatial intelligence and students with mathematical logic intelligence taught with PBL model.

\section{RECOMMENDATIONS}

Based on the research findings, it is recommended that:

a. To improve student mathematics achievement, the PBL model using PMR is more suitable.

b. In determining the learning model, the teacher must consider the characteristics of students, especially mathematical logic intelligence and spatial intelligence.

c. Further research is needed to apply the PBL model using PMR by considering mathematical logic intelligence, spatial intelligence, gender, and student learning environments in teaching mathematics to all levels of education with different materials to improve student mathematics achievement.

\section{REFERENCES}

Adeniji, S. M., Ameen, S. K., Dambatta, B. U., \& Orilonise, R. (2018). Effect of mastery learning approach on senior school students' academic performance and retention in circle geometry. International Journal of Instruction, 11(4), 951-962.

Arends, R. (2012). Learning to teach. New York: McGraw-Hill.

Barnes, H. (2004). Realistic mathematics education: Eliciting alternative mathematical conceptions of learners. African Journal of Research in Mathematics, Science and Technology Education, 8(1), 53-64. 
Bremigan, E. G., Bremigan, R. J., \& Lorch, J. D. (2011). Mathematics for secondary school teachers. American Mathematical Society.

DeMelo, R. L. (2007). The general principles of reality a. Unification of physics. Ontario: GPOFR.

Eggen, P., \& Kauchak, D. (2012). Strategies and models for teachers: Teaching content and thinking skills. Boston: Pearson.

Estes, T. H., \& Mintz, S. L. (2016). Instruction: A model approach. New York: Pearson.

Firdaus, F. M. (2017). Improving primary students' mathematical literacy through problem based learning and direct instruction. Educational Research and Reviews, 12(4), 212-219.

Gardner, H. (2011). Frames of mind: The theory of multiple intelligences. New York: Basic Book.

Hidayah, I. (2015). Model of independent working group of teachers and its effectiveness towards the elementary school teacher's ability in conducting mathematics learning. Procedia-Social and Behavioral Sciences, 214, 43-50.

Hussain, M., Sahudin, S., Samah, N. H. A., \& Anuar, N. K. (2019). Students perception of an industry-based approach problem-based learning (PBL) and their performance in drug delivery courses. Saudi Pharmaceutical Journal, 27(2), 274-282.

Ibrahim, M. E., Al-Shahrani, A. M., Abdalla, M. E., Abubaker, I. M., \& Mohamed, M. E. (2018). The effectiveness of problem-based learning in the Acquisition of Knowledge, soft skills during basic and preclinical sciences: medical Students' points of view. Acta Informatica Medica, 26(2), 119.

Jesseph, D. M. (2010). Berkeley's philosophy of mathematics. University of Chicago Press.

Kemendikbud R. I. (2011). Survey International PISA (Programme for International Student Assessment, Kemendikbud, Jakarta.

Kilbane, C. R., \& Milman, N. B. (2013). Teaching models: Designing instruction for $21^{\text {st }}$ - century learners. Pearson.

Kirkland, K. (2010). Physical sciences: Notable research and discoveries. New York: Facts on File.

Korn, G. A., \& Korn, T. M. (2000). Mathematical handbook for scientists and engineers: Definitions, theorems, and formulas for reference and review. Dover Publication.

Lai, Y., Zhu, X., Chen, Y., \& Li, Y. (2015). Effects of mathematics anxiety and mathematical metacognition on word problem solving in children with and without mathematical learning difficulties. PlosOne, 10(6), 0130570. 
Lowenstein, A. J., \& Bradshaw, M. J. (2004). Fuszard's innovative teaching strategies in nursing. Jones and Bartlett Publishers.

Mckee, L. (2004). The accelerated trainer using accelerated learning techniques to revolutionize your training. Burlington: Gower Publishing.

Montgomery, D. C. (2017). Design and analysis of experiments. John Wiley \& Sons.

Mbugua, Z. K., \& Muthomi, M. W. (2014). Effectiveness of differentiated instruction on secondary school students achievement in mathematics. International Journal of Applied Science and Technology, 4(1), 116-122.

Nani, A. M. Y., \& Latuconsina, N., (2015). Effect of learning and intelligence approaches to mathematics towards learning outcomes mathematics students of class viii state middle school 1 Podong North Sumatra District Taralar, MaPan: Journal of Mathematics and Learning, 3(2).

Ormrod, J., Anderman, E. M., \& Anderman, L. (2016). Educational psychology: Developing learners. Boston: Pearson.

Orton, A., \& Frobisher, L. (2004). Insights into teaching mathematics. A\&C Black.

Özokcu, O., Akçamete, G., \& Özyürek, M. (2017). Examining the effectiveness of direct instruction on the acquisition of social skills of mentally retarded students in regular classroom settings. Journal of Education and Training Studies, 5(4), 214-226.

Pehlivan, A., \& Durgut, M. (2017). The effect of logical-mathematical intelligence on financial accounting achievement according to multiple intelligence theory. Journal of Education and Social Policy, 4(3), 132 - 139.

Perutz, M. B., \& Jenkin. (1989). The virtues of science and scientists. journal New Scientist, Volume 123(1677).

Phakiti, A. (2014). Experimental research methods in language learning. Bloomsbury Publishing.

Pradnyana, B. P., Marhaeni, A., \& Candiana, I. M. (2013). The effect of problem based learning on learning motivation and mathematics learning outcomes, E-journal of the University of Education Ganesha Postgraduate Program, Volume 3.

Ramirez, H., \& Jones, D. (2012). effects of direct instruction and corrective feedback on second language acquisition. National Forum of Educational Administration \& Supervision Journal, 30(1), 64-87.

Rasmussen, C. L., \& King, K. D. (2000). Locating starting points in differential equations: A realistic mathematics education approach. International Journal of Mathematical Education in Science and Technology, 31(2), 161-172.

Ratnasari, I. T., Wardani, S., \& Nuswowati, M. (2018). The impact of multiple intelligences approaches through quantum teaching model toward the scientific attitude 
and science learning outcomes in the fourth-grade students. Journal of Primary Education, 7(2), 146-154.

Reigeluth, C. M., \& Carr-Chellman, A. A. (Eds.). (2009). Instructional-design theories and models, volume III: Building a common knowledge base. Routledge.

Rohmah N. (2013). Upaya Meningkatkan Kemampuan Menyelesaikan Masaah Matematika Melalui Pembelajaran Berbasis Masalah. Jurnal Pendidikan Matematika STKIP Sidoarjo, 1(1).

Roesdiyanto, (2014), The influence of multiple intelligence approach on the physical education learning towards for character improvement. Journal Asian Social Science, 10(5), 91-97.

Ross, B. H. (2005). The psychology of learning and motivation: Advances in research and theory. San Diego: Academic Press.

Singh, A. D., Raghunathan, S., Robeck, E., \& Sharma, B. (2019). Cases on smart learning environments. IGI Global.

Sumirattana, S., Makanong, A., \& Thipkong, S. (2017). Using realistic mathematics education and the DAPIC problem-solving process to enhance secondary school students' mathematical literacy. Kasetsart Journal of Social Sciences, 38(3), 307-315.

Taylor, A. (2013) Card magic and my mathematical discoveries. St, Raleigh: Lulu Publishing.

Widjaja, Y. B., \& Heck, A. (2003). How a realistic mathematics education approach and microcomputer-based laboratory worked in lessons on graphing at an Indonesian junior high school. Journal of Science and Mathematics Education in Southeast Asia, 26(2), 151 .

Widyatiningtyas, R., Kusumah, Y. S., Sumarmo, U., \& Sabandar, J. (2015). The impact of problem-based learning approach to senior high school students' mathematics critical thinking ability. Journal on Mathematics Education, 6(2), 107-116.

Wu, H. (2011). Understanding numbers in elementary school mathematics. Providence: American Mathematical Society.

Yarmohammadian, A. (2014). The relationship between spatial awareness and mathematic disorders in elementary school students with learning mathematics disorder. Psychology and Behavioral Sciences, 3(1), 33-40.

Zhang, D. (2017). Effects of visual working memory training and direct instruction on geometry problem solving in students with geometry difficulties. Learning Disabilities: A Contemporary Journal, 15(1), 117-138. 